\title{
Import substitution of products for traumatology and orthopaedics in the Russian Federation. Challenges and unsolved problems
}

\author{
S.V. Bushnev ${ }^{1}$, N.V. Zagorodny ${ }^{1}$, A.V. Burtsev ${ }^{2}$, M.V. Stogov ${ }^{2}$, E.N. Ovchinnikov' ${ }^{2}$ A.V. Gubin ${ }^{1}$ \\ ${ }^{1}$ National Medical Research Center of Traumatology and Orthopedics n.a. N.N. Priorov, Moscow, Russian Federation \\ ${ }^{2}$ Ilizarov National Medical Research Centre for Traumatology and Orthopedics, Kurgan, Russian Federation
}

In mid-September 2019 at the BiotechMed 2019 Conference, the Ministry of Industry and Trade of the Russian Federation (MIT RF) announced the implementation of the project on localization and import substitution of medical products (MP) for traumatology and orthopedics (TO). The main localization site was determined by the Federal State Unitary Enterprise the Central Scientific Research Institute of Traumatology and Orthopedics (FGUP "CITO") subordinated to the Ministry of Industry and Trade of the Russian Federation.

Undoubtedly, this initiative is not unique and remains a part of the consistent policy of the Government of the Russian Federation (RF) aimed at increasing the share of domestic goods in the domestic market and stimulating export potential. Despite the obvious successes in the agricultural sector, food industry and automotive industry, for successful implementation of import substitution in the new segment of the economy it is necessary to take into account the unique industry specifics, clearly understand the effect on all participants and counter-parties of a particular economic chain. The production of medical devices for maintenance and repair is highly knowledge-intensive, has a significant degree of industrial segmentation and globalization, and is closely integrated with the clinical community. The purpose of this publication is to discuss industry specifics, including legal and regulatory specifics, and to identify all parties in the economic relationship, from production to the consumer.

\section{Historical Context}

According to the definition given by A. Vilenskyy and A. Dekhanov, "import substitution is a purposeful state policy aimed at adopting a set of stimulating and protective measures that will allow for the production and distribution of analogous foreign products on its own territory and, if possible, under domestic brands".

It is believed that the beginning of import substitution in Russia was May 2014, when the President of the Russian Federation formed the "List of instructions on additional measures to stimulate economic growth" as a response to international economic sanctions imposed on Russia.
Based on the Presidential instructions, the RF Government approved the Plan of Assistance for Import Substitution in Industry No. 1936-r on September 30, 2014, according to which on March 31, 2015 the RF MIT approved the plan of measures on import substitution in the medical industry of the Russian Federation. However, it is necessary to recall the state program developed back in 2010-2012 "The Development of the pharmaceutical and medical industry" for 2013-2020, which defined the tasks to increase the share of domestic MP up to $40 \%$, as well as to increase their exports up to $16 \%$, which remains the main target indicators to date.

In May 2015, Resolution No. 102 "On limitations and conditions for admission of certain types of MP originating from foreign countries for the purpose of procurement to meet state and municipal needs" was adopted, the so-called "third redundant" rule (102nd Resolution). The original Regulation provided a list of 111 foreign-made MPs which turnover is restricted and admission to public procurement is possible only if two or fewer domestic manufacturers are not in the bidding. The Ordinance has gone through several revisions to clarify and supplement the list of products subject to the restrictive measures. It is noteworthy that orthopaedic implants were included in this document only in June 2019, when the government approved the final version of the regulation.

The effectiveness of this document is constantly questioned due to its restrictive orientation, which causes irritation not only from manufacturers of $\mathrm{MP}$, but also leads to collusion between the customer and the supplier, promoting jointly imported products. Even the Federal Antimonopoly Service (FAS) has publicly acknowledged the ineffectiveness of this regulation and lobbied for its repeal.

In our opinion, in the production of MP for traumatology and orthopaedics, the 102nd Resolution has become an important legal and economic basis that has shown the relevance and expediency of investment in this industry for both domestic players and foreign companies. The period of 2015-2018 specifically accounts for the growth of activity among domestic producers and an increase in

Bushnev S.V., Zagorodny N.V., Burtsev A.V., Stogov M.V., Ovchinnikov E.N., Gubin A.V. Import substitution of products for traumatology and orthopaedics in the Russian Federation. Challenges and unsolved problems. Genij Ortopedii, 2020, vol. 26, no 2, pp. 161165DOI 10.18019/1028-4427-2020-26-2-161-165 
localization initiatives. For example, in 2015 Smith \& Nephew bought the distribution company Deost and its affiliated manufacturer DC. In 2015, the Russian-German manufacturer of ceramics, Moje Ceramic Implants, will open a second production site. On June 1, 2018 the Hungarian manufacturer of products for traumatology and orthopedics Sanatmetal started localization production of its products in Obninsk. In December 2018 ZAO Trek-E Composite, together with the state corporation Rosatom established the production of endoprosthetics on the basis of high-tech research from the Bochvar Institute for inorganic materials.

In 2015 the MIT RF initiates the project "Reconstruction and technical re-equipment of production in order to ensure production of import substitution medical devices for orthopaedics, traumatology and prosthetics of FGUP "CITO", Moscow".

As we can see, the measures supported by the government to stimulate domestic manufacturers along with the programs for transition of the economy to an innovative path of development create the basis for domestic developments and manufacture the products for traumatology and orthopaedics. Nevertheless, the existing objective barriers to the development of import substitution in the Russian Federation require coordinated work on the part of regulatory authorities, manufacturers and the orthopaedic community.

Market understanding. Influence of market analysis on investment decisions

Market research, continuous monitoring and regular analysis is a basic element of any investment activity. The knowledge gained during market research not only forms a knowledge base on the competitive landscape, new trends and emerging demands, but also helps to adequately assess business risks and identify the unique advantages of its products. As the information technology industry shows, a product alone, even one with technological superiority, is not enough for success. We need market knowledge and understanding.

The domestic MP market for traumatology and orthopedics is extremely opaque. For today, the orthopedic community and representatives of the domestic industry do not have reliable economic knowledge on the volume, capacity, structure and share distribution of the MP market.

Even the data from analytical commercial reports, which are operated by foreign manufacturers and domestic private investors, should be treated with caution because of the lack of a clear methodological approach and generally accepted sources of primary data.

Serious research is needed, conducted in close integration with leading orthopaedic centers, orthopaedic professional communities, representatives of domestic and foreign industry, federal and regional executive authorities.

In order to make import substitution not only a political slogan, it is expedient to conduct research on the cost of domestic implants in comparison with the products of foreign manufacturers, to assess the impact of rouble volatility on the volume of import of medical devices for traumatology and orthopedics, as well as to analyze pricing in the industry for the last 10 years.
Import substitutions in traumatology and orthopaedics and economic chain participants

When discussing import substitution of MP in traumatology and orthopaedics in Russia, we are mainly talking about various economic and legislative stimulating measures to support MP producers. It is as if they are the only participants in economic relations, and the success or failure of this state initiative depends on them. Ignoring the needs and interests of other participants will lead to misunderstanding of import substitution goals and objectives, which will affect the success of the whole process.

In the world professional publications the following are accepted as participants of economic relations in our field: patients, orthopedists, medical institutions, manufacturers, insurers (or other payers), and the regulator (state). For our country, we need to add one more interested party to this list - suppliers (distributors). There are practically no direct sales in Russia, and distributors are active and full participants in economic cooperation.

\section{Patient Community}

From an ethical point of view, patients should be provided with the right to make independently educated decisions about their life and health in accordance with their life principles, values and beliefs, and this should be the basis of the general clinical approach.

When we talk about increasing the share of domestically produced implantable products, we must understand that without the voluntary consent of the patient community it will be impossible to achieve the target indicators. Today, patients have extremely low product patriotism, and have developed an affinity to foreign implants. This trend cannot be changed by administrative means alone or by pressure from the clinical community. Thanks to the unprecedented availability of professional information and advances in information technology, patients are becoming more and more active and prepared participants in clinical decision making. There is a need for serious clinical research, long-term observation, and a national register to prove the safety and efficacy of domestic implants, and not just of the political climate.

\section{Orthopaedic Community}

The relations between domestic manufacturers of MP and orthopaedic surgeons are extremely utilitarian and opportunistic, aimed mainly at increasing short-term sales without any coordinated long-term strategy.

The revival of the domestic orthopaedic medical industry requires vertical integration between the clinical community and domestic manufacturers in an innovative, evidence-based and economic aspect.

In order to stimulate the innovation potential, a transparent and favorable mechanism for all beneficiaries of intellectual activity (doctor, medical institution, government, industry) needs to be developed for the formation and licensing of intellectual property.

No administrative resource can provide the domestic medical industry with $40 \%$ of the domestic market, let alone export potential, without scientifically based clinical data. It is necessary to develop a comprehensive multiyear scientific and practical program for the formation 
of evidence-based clinical database on the safety and efficiency of domestic MP.

\section{Medical Institutions}

It would seem that administrators of clinical centres would be extremely interested in cheaper domestic products, but, as we can see from practice, they prefer products from Western manufacturers. This is not always due to some hidden economic reasons. Often it is just a more convenient and predictable option. Western companies and their distributors have excellent logistics, ensuring fast delivery or replacement of products, providing quality tools and investing in surgeons' training, which have a significant impact on safety and clinical results.

Domestic manufacturers need to think about establishing clinical support centers for training and research; providing quality ergonomic tool kits; and establishing a reliable logistics chain to ensure that clinical centers operate smoothly.

\section{Manufacturers}

The domestic medical industry is often criticized for its weakness and low innovative potential. Most domestic products are not original and are copies of successful foreign solutions. In our opinion, this is a justified criticism. This situation is the result of the lack of proper cooperation with the clinical community and leading medical centre. In the Russian Federation there are clinical centre with clinical, engineering and even production expertise that have experience in implementing their products in the world markets, which could help domestic companies to form a more balanced and innovative portfolio.

The domestic medical industry should adjust its marketing and investment strategy by providing budgets for training and education activities, as well as financing of the national register and prospective clinical trials.

\section{Suppliers (Distributors)}

Suppliers are one of the important elements in orthopaedic industrial cooperation. When it comes to logistics and customer support, their role and impact on industry development is often underestimated. Direct contact with hospital administrators, personal relationships with surgeons and their supply chain enable suppliers to directly influence the volume of implanted products. The domestic medical industry will either have to build up its distribution network or provide additional discounts that can ensure the loyalty of distributors to domestic brands.

\section{Insurance companies and other payers}

Most of the market redistribution of traumatological and orthopaedic MPs will come from high-tech assistance (HTMC), the Federal Compulsory Medical Insurance Fund (FCMIF) and the territorial compulsory medical insurance funds (TCMIF), which are the main revenue streams for state medical institutions. We assume that the marketing focus of domestic companies and their administrative resources will be directed to the state segment.

Private companies operating in the segment of additional health insurance and personal funds of citizens will be more demanding to have an evidence base for the safety and efficiency of domestic MP.

For ambitious domestic companies seeking to enter the international market, this segment can serve as a good test site for identifying competitive advantages over products of world leaders.

\section{Regulator}

Undoubtedly, the state is interested in creating a strong domestic medical industry.

It is not only political independence in the context of strengthening international sanctions, the reduction of economic risks associated with currency fluctuations, but also a purposeful policy to diversify the economy, create additional jobs and create new centers of knowledge and competence.

In addition to the above legislative initiatives on import substitution for a whole range of industries, we would like to see more targeted, sectoral support measures. Such measures could include financing and maintenance of the national register of MP, regulatory support and implementation of a single national electronic map of a patient with bone and muscular pathology, which would simplify data entry into the register, increase its efficiency, and reduce its maintenance costs. These two steps would provide the clinical community with the necessary tools to form an evidence-based clinical database on the safety and efficacy of domestic MP, and would significantly reduce the financial burden on the reviving domestic medical industry.

Without the help of the state it would be impossible to solve a number of regulatory aspects and legal conflicts, without elimination of which the industry cannot develop dynamically. Some of them will be discussed a bit further.

Legal support of import substitution in traumatology and orthopedics deserves a separate study. Here we just want to give one example that directly restricts the development of MP production in Russia.

Restrictions imposed by the federal law "On the basis of health protection for the citizens in the Russian Federation" from 21.11.2011 N 323-FZ (N 323-FZ)

Creation of high-tech products is impossible without adequate compensation to intellectual donors for their ideas and assistance in development and implementation. However, in accordance with Article 74 N 323-FZ, medical workers are prohibited to accept any rewards, except for clinical approbation and teaching activities. It is also prohibited to enter into agreements on the prescription or recommendation of medicines and medical products.

These provisions, which are clearly important in terms of anti-corruption activities, need to be clarified in the light of federal import substitution initiatives.

Features of conducting clinical trials of new products in the Russian Federation. The suggested solution

To conducting clinical trials of medical devices for registration purposes is the final stage for the product's entry into the market. As our experience shows, a manufacturer of medical devices often does not have a sufficient level of competence when applying to a medical organization and, very often, the manufacturer delegates the function of organizing clinical trials to consulting firms or the organization on the basis of which the clinical trial is planned. This is often justified not only from the point of view of economic benefit, but also because according to national rules, clinical testing for devices of $2 \mathrm{a}, 2 \mathrm{~b}$, and 3 
risk classes is the second stage of registration of the device, following examination of quality, efficiency, and safety. This two-step procedure allows for the suspension of state registration of medical devices, which manufacturers use as a time to "prepare" for clinical trials. However, this procedure significantly slows down the registration process.

As of today, the stage of clinical trials of most modern domestic medical devices produced as a part of import substitution is in the form of analysis and evaluation of clinical data without human participation. This significantly reduces the cost of the registration procedure for the manufacturer. Additionally, this is also facilitated by the fact that registered import substitution products, as a rule, have a significant number of registered counterparts, which confirmation of compliance enables to conduct clinical trial procedures without human participation. Unfortunately, this often results in the manufacturer's assessment of the clinical trial phase as a necessary formality, without taking into account the test results for the further development of their product.

It would seem that all that is indicated above should have ensured a certain development of domestic import substitution. However, the way of simple re-registration of imported products on the territory of the Russian Federation was easier and more profitable, which economically did not contribute to the development and creation of (new, original, and not analogous) import substitution products and it also slowed the development of domestic counterparts of existing products.

The way out of this situation is not obvious yet because currently there is a transition of procedures for registration of medical devices from the rules of national legislation to the procedure of registration in accordance with the rules of the EAU.
Conducting clinical trials according to this procedure is still a rare experience. An obvious advantage of this registration procedure is the single-stage procedure because it leads to the possibility of interaction between the manufacturer and the clinic already at the stage of product creation. The obvious disadvantage is the impossibility of conducting a clinical trial in the form of analysis and evaluation of clinical data without human participation. The last example significantly increases the costs for registration of import substitution products with analogues. Therefore, we can expect that the transition to registration of products within the EAU may become a significant (primarily costly) problem for manufacturers of analogous medical devices as part of import substitution.

However, in our opinion, for the manufacturers of new (original) non-analogous medical devices, the registration procedure under the EAU, unlike the current national procedure, looks more convenient, acceptable, and increases their competitiveness. It implies: 1) onestage registration procedure; 2 ) early interaction with the clinic. On the other hand, determining how ready a modern manufacturer is (most importantly financially) to create a new product from its development to implementation (registration) is difficult to answer.

Thus, at present, there is a rather ambiguous situation for the import substitution of medical devices. On the one hand, the transition to new registration procedures facilitates the creation and development of non-analogous medical devices. On the other hand, the need for import substitution of analogous medical devices, especially as current practice shows, in emergency situations (pandemics and sanctions), requires maintaining "simplified" registration procedures. In such cases, the ability to conduct clinical trials in the form of evaluation and compliance without human involvement must be preserved.

\section{CONCLUSIONS}

The import substitution program is a necessary and long-awaited government initiative. Its successful implementation depends on the involvement of all participants in orthopaedic cooperation. Thorough and transparent integration between domestic producers and the clinical community in terms of ethics and conflict of interest should provide the industry with the necessary clinical data to form innovative competitive products.
The development, implementation and commercialization of products should take place without clinical and administrative pressure, on the basis and principles of evidence-based medicine, and with the active participation of the patient community. A regular dialogue between all participants of the processes is necessary to overcome legal and regulatory restrictions and to form a single long-term development program that is understandable to everyone.

\section{REFERENCES}

1. BIOTEKHMED-2019: IV Ezhegodnyy Mezhdunarodnyy Forum (g. Gelendzhik, 16-17 sentyabrya, 2019 (BIOTEKHMED-2019. IV Annual International Forum. Gelendzhik, September 16-17, 2019). (in Russian) Available at: https://biotechmedconf.ru/wp-content/uploads/pdf/2019/ otchet/biotechmed-report-2019.pdf. (accessed 01.05.2020).

2. Zavershenie realizatsii proekta «Rekonstruktsiya $i$ tekhnicheskoe perevooruzhenie proizvodstva s tselyu obespecheniya vypuska importozameshchayushchikh meditsinskikh izdeliy dlya ortopedii, travmatologii i protezirovaniya in FGUP "TsITO». Moskva [Implementation Completion of the Project "Reconstruction and Technical Re-equipment of Production in order to Ensure the Release of Import-substituting Medical Products for Orthopaedics, Traumatology and Prosthetics in Federal State Unitary Enterprise "Research Centre for Traumatology and Orthopaedics". Moscow]. (in Russian) Available at: https://citopro.ru/news/company/3892/. (accessed 01.05.2020).

3. URL: http://kremlin.ru/acts/assignments/orders/23900. (accessed 01.05.2020).

4. URL: http://government.ru/info/22804/. (accessed 01.05.2020).

5. Russian Federation. Order of the Ministry of Industry and Trade of the Russian Federation (Ministry of Industry and Trade of Russia) No 655 of March 31, 2015, Ob utverzhdenii plana meropriyatiy po importozameshcheniyu v otrasli meditsinskoy promyshlennosti Rossiyskoy Federatsii [On approval of the plan on import substitution measures in the medical industry of the Russian Federation]. (in Russian) Available at: https://gisp.gov.ru/upload/iblock/940/655.pdf. (accessed 01.05.2020).

6. Gosudarstvennaya Programma «Razvitie Farmatsevticheskoy i Meditsinskoy Promyshlennosti» na 2013-2020 gody [State Program "Development of Pharmaceutical and Medical Industry" for 2013-2020]. Minpromtorg Rossii [Ministry of Industry and Trade of Russia]. (in Russian) Available at: http://minpromtorg.gov.ru/common/upload/files/docs/MinProm_02.06.14.pdf. (accessed 01.05.2020). 
7. Postanovlenie Pravitelstva № 102 ot 5 fevralya 2015 g. "Ob ogranicheniyakh i usloviyakh dopuska otdelnykh vidov meditsinskikh izdeliy, proiskhodyashchikh iz inostrannykh gosudarstv, dlya tseley osushchestvleniya zakupok dlya obespecheniya gosudarstvennykh i munitsipalnykh nuzhd" [Government Regulation No 102 of February 5, 2015 "On the restrictions and conditions for the admission of certain types of medical products originating from foreign states for the purpose of procurement for providing state and municipal needs"]. (in Russian) Available at: http://pravo.gov.ru/proxy/ips/?docbody=\&nd=102367173 (accessed 01.05.2020).

8. Postanovlenie Pravitelstva № 813 ot 26 iyunya 2019 g. "O vnesenii izmeneniy v perechen otdelnykh vidov meditsinskikh izdeliy, proiskhodyashchikh iz inostrannykh gosudarstv, $\mathrm{v}$ otnoshenii kotorykh ustanavlivayutsya ogranicheniya dopuska dlya tseley osushchestvleniya zakupok dlya obespecheniya gosudarstvennykh i munitsipalnykh nuzhd" [Government Regulation No 813 of June 26, 2019 “On amendments to the list of certain types of medical products originating from foreign states in respect of which access restrictions are established for the purpose of procurement for providing state and municipal needs"]. (in Russian) Available at: http://pravo.gov.ru/proxy/ips/?docbody=\&prevDoc=102367173\&backlink=1\&\& nd=102565683. (accessed 01.05.2020).

9. Shubina D., Rechkin E. Pochemu na rynke medizdeliy ne rabotaet importozameshchenie [Why import substitution does not work in the medical product market]. Vademecum: delovoy zhurnal ob industrii zdravookhraneniya [Vademecum: health industry business journal]. 2017, June 8. (in Russian) Available at: https://vademec.ru/article/v_rossii_rezko_snizilis_goszakupki_otechestvennykh_shpritsev/ (accessed 01.05.2020).

10. Chesnokova O. FAS vystupila za otmenu pravila «tretiy lishniy» [FAS /Federal Antimonopoly Service/ advocated the abolition of the rule "third extra"]. Vademecum: delovoy zhurnal ob industrii zdravookhraneniya [Vademecum: health industry business journal]. 2017, March 6. (in Russian) Available at: https://vademec.ru/news/2017/08/17/fas-predlagaet-oslabit-pravilo-tretiy-lishniy-na-goszakupkakh-medizdeliy/ vademec.ru/news/2017/03/06/fas-prosit-pravitelstvo-otmenit-pravilo-tretiy-lishniy/ (accessed 01.05.2020).

11. Britanskaya Smith \& Nephew pokupaet rossiyskuyu meditsinskuyu kompaniyu «Deost» [British Smith \& Nephew buys “Deost”, a Russian medical company]. (in Russian) Available at: https://www.kommersant.ru/doc/2764816 (accessed 01.05.2020).

12. «Moye Keramik-Implantate» rasshirila proizvodstvo v Tomskoy OEZ [“Moye Ceramic-Implantate” has expanded production in the Tomsk Special Economic Zone (SEZ)]. Available at: https://www.kommersant.ru/doc/2856980 (accessed 01.05.2020).

13. «Sanatmetal SNG» predstavit na EOF innovatsionnyi instrumentarii i provedet vorkshop po ustanovke implantatov ["Sanatmetal CIS” will present innovative tools at the EOF and will conduct a workshop on implant placement]. (in Russian) Available at: http://eoforum.ru/news/ Sanatmetal_SNG-_predstavit_na_EOF_innovations (accessed 01.05.2020).

14. Mylnikov M. «Rosatom» lokalizoval proizvodstvo endoprotezov za 677 mln. rubley ["Rosatom” localized the production of implants for 677 million rubles]. Vademecum: delovoy zhurnal ob industrii zdravookhraneniya [Vademecum: health industry business journal]. 2018, December 21. (in Russian) Available at: https://vademec.ru/news/2018/12/21/rosatom-lokalizoval-proizvodstvo-endoprotezov/ (accessed 20.05.2020).

15. Rasporyazhenie Pravitelstva RF ot 2 oktyabrya 2015 goda № $1955-\mathrm{r}$ “Ob otnesenii k vedeniyu Minpromtorga Rossii Federalnogo Gosudarstvennogo Unitarnogo Predpriyatiya "TsITO" Ministerstva Zdravookhraneniya i Sotsialnogo Razvitiya Rossiyskoy Federatsii, nakhodyashchegosya v vedenii Minzdrava Rossii [Order of the RF Government No 1955-r of October 2, 2015 "On attribution of CITO Federal State Unitary Enterprise of the RF Ministry of Health and Social Development, which is under the jurisdiction of Russia Ministry of Health, to the jurisdiction of the Ministry of Industry and Trade of Russia”]. (in Russian) Available at: http://docs.cntd.ru/ document/420306031 (accessed 20.05.2020).

16. Burgers J.H., Van Den Bosch F.A.J., Volberda H.W. Why New Business Development Projects Fail: Coping with the Differences of Technological versus Market Knowledge (October 30, 2007). ERIM Report Series Reference No. ERS-2007-072-STR. Available at: https:// ssrn.com/abstract $=1032756$.

17.Wilson N.A., Ranawat A., Nunley R., Bozic K.J. Executive summary: aligning stakeholder incentives in orthopaedics. Clin. Orthop. Relat. Res., 2009, vol. 467, no. 10, pp. 2521-2524. DOI: 10.1007/s11999-009-0909-4.

18. Devereux C. Models of the physician-patient relationship. JAMA, 1992, vol. 268, no. 11, pp. 1410-1413. DOI: 10.1001/jama.268.11.1410b.

19. Townsend A., Leese J., Adam P., McDonald M., Li L.C., Kerr S., Backman C.L. eHealth, Participatory medicine, and Ethical Care: A Focus Group Study of Patients' and Health Care Providers' Use of Health-Related internet Information. J. Med. Internet Res., 2015, vol. 17, no. 6, pp. e155. DOI: 10.2196/jmir.3792.

20. Franklin M., Lewis S., Willis K., Rogers A., Venville A., Smith L. Controlled, Constrained, or Flexible? How Self-Management Goals Are Shaped By Patient-Provider Interactions. Qual. Health Res., 2019, vol. 29, no. 4, pp. 557-567. DOI: 10.1177/1049732318774324.

21.Elwyn G., Durand M.A., Song J., Aarts J., Barr P.J., Berger Z., Cochran N., Frosch D., Galasiński D., Gulbrandsen P., Han P.K.J., Härter M., Kinnersley P., Lloyd A., Mishra M., Perestelo-Perez L., Scholl I., Tomori K., Trevena L., Witteman H.O., Van der Weijden T. A three-talk model for shared decision making: multistage consultation process. BMJ, 2017, vol. 359, pp. j4891. DOI: 10.1136/bmj.j4891.

22.O'Connor B., Pollner F., Fugh-Berman A. Salespeople in the Surgical Suite: Relationships between Surgeons and Medical Device Representatives. PLoS One, 2016, vol. 11, no. 8, pp. e0158510. DOI: 10.1371/journal.pone.0158510.

23. Johnson J., Hutchison K. They Know How to Work It, That's Their Focus in Life: The Complex Role of Industry Representatives in Surgical Innovation. J. Empir. Res. Hum. Res. Ethics, 2018, vol. 13, no. 5, pp. 461-474. DOI: 10.1177/1556264618785037.

24. Statya 74 Federalnogo Zakona № 323-FZ «Ob osnovakh okhrany zdorovya grazhdan v RF» ot 21.11.2011, Ogranicheniya, nalagaemye na meditsinskikh rabotnikov i farmatsevticheskikh rabotnikov pri osushchestvlenii imi professionalnoy deyatelnosti [Article 74 of the Federal Law No 323-FZ "On the basics of protecting the health of citizens in the Russian Federation" of 21.11.2011, Restrictions on medical and pharmaceutical workers in their professional activities]. (in Russian) Available at: http://www.consultant.ru/document/cons_doc_LAW_12 1895/8eee23730b6e2d771575ba85beed80646a00ede9/ (accessed 20.05.2020).

Received: 12.05 .2020

\section{Information about the authors:}

1. Sergey V. Bushnev,

National Medical Research Center of Traumatology and Orthopedics n.a. N.N. Priorov, Moscow, Russian Federation

2. Nikolay V. Zagorodny, M.D., Ph.D., Professor,

National Medical Research Center of Traumatology and Orthopedics n.a. N.N. Priorov, Moscow, Russian Federation

3. Alexander V. Burtsev, M.D., Ph.D.,

Ilizarov National Medical Research Centre for Traumatology and Orthopedics, Kurgan, Russian Federation,

Email: bav31rus@mail.ru

4. Maksim V. Stogov, Ph.D. of Biological Sciences,

Ilizarov National Medical Research Centre for Traumatology and Orthopedics, Kurgan, Russian Federation,

Email: stogo_off@list.ru

5. Evgeny N. Ovchinnikov, Ph.D. of Biological Sciences,

Ilizarov National Medical Research Centre for Traumatology and Orthopedics, Kurgan, Russian Federation

6. Alexander V. Gubin, M.D., Ph.D.,

National Medical Research Center of Traumatology and Orthopedics n.a. N.N. Priorov, Moscow, Russian Federation,

Email: shugu19@gubin.spb.ru 